Т. К. Губарь, Л. Л. Алексеева, В. Г. Стуров. Роль полиморфизма генов тромбофилии в развитии осложнений беременности родов у женщин Республики Бурятия

УДК 618.3-06

DOI: $10.18101 / 2306-1995-2019-1-31-38$

\title{
РОЛЬ ПОЛИМОРФИЗМА ГЕНОВ ТРОМБОФИЛИИ В РАЗВИТИИ ОСЛОЖНЕНИЙ БЕРЕМЕННОСТИ РОДОВ У ЖЕНЩИН РЕСПУБЛИКИ БУРЯТИЯ
}

\author{
(C) Губарь Татьяна Константиновна \\ аспирант, \\ кафедра акушерства и гинекологии, \\ Бурятский государственный университет им. Д. Банзарова, \\ врач акушер-гинеколог, \\ медицинский центр «Диамед» \\ Россия, 670000, Бурятия, г. Улан-Удэ, ул. Смолина, 24a \\ E-mail: gtk71@mail.ru

\section{(C) Алексеева Лилия Лазаревна} \\ доктор медицинских наук, доцент, \\ кафедра акушерства и гинекологии, \\ Бурятский государственный университет им Д. Банзарова, \\ заместитель главного врача по лечебной работе, \\ Республиканский перинатальный центр \\ Россия, 670000, Бурятия, г. Улан-Удэ, ул. Смолина, 24а \\ E-mail: 1.alekseeva09@mail.ru
}

\section{(C) Стуров Виктор Геннадьевич}

доктор медицинских наук, профессор,

центр постдипломного медицинского образования,

Институт переподготовки и повышения квалификации,

Новосибирский национальный исследовательский государственный университет Минобрнауки РФ

Россия, 630090, Новосибирск, ул. Пирогова, д. 2

E-mail: sturov@mail.ru

При проведении анализа результатов обследования у 96 жительниц республики Бурятия (из них 20 женщин бурятской национальности, проживающих в отдаленном районе, 26 женщин бурятской национальности, проживающих в городе, 50 женщин русской этнической группы), не было выявлено достоверно значимых различий в развитии осложнений беременности и исходов родов, хотя частота встречаемости патологических генотипов, предрасполагающих к развитию тромбофилии больше в европейской популяции.

Ключевые слова: тромбофилия, генные дефекты, осложнения беременности, паритет, гомоцистеин.

Для цитирования:

Губарь Т. К., Алексеева Л. Л., Стуров В. Г. Роль полиморфизма генов тромбофилии в развитии осложнений беременности родов у женщин Республики Бурятия // Вестник Бурятского государственного университета. Медицина и фармация. 2019. Вып. 1. С. 31-38.

Под тромбофилией понимают наследственные или приобретенные аномалии в системе гемостаза, предполагающих к развитию тромбоза [2]. 
Женщины с приобретенной и наследственной тромбофилией находятся в группе повышенного риска по развитию тромботических и гестационных осложнений: синдром потери плода, тяжелой преэклампсии, отслойки хориона, тромбоза во время беременности и в послеродовом периоде. Кроме того, различного рода тромбоэмболические осложнения остаются одной из ведущих причин материнской смертности в большинстве экономически развитых стран Европы и Азии $[4,1]$.

При тромбофилиях создаются условия для нарушения процессов имплантации, плацентации, роста плода, развивается системная эндотелиальная дисфункция, активизируется противоспалительный ответ и формируется прокоагуляционный потенциал свертывающей системы крови [2].

По данным авторов наличие тромботических дефектов увеличивает риск развития осложнений при беременности в $3-8$ раз $[6,7]$.

В тоже время, сведения о распространенности и клинической значимости полиморфизмов и мутаций генов тромбофилии не всегда однозначны. Это обусловлено и различиями в общепопуляционной частоте полиморфизмов в генах тромбофилии в географических районах и синергизмом врожденных и приобретенных дефектов гемостаза [6].

Цель исследования: Установить наличие или отсутствие различий по частоте встречаемости генных дефектов в системе гемостаза и их взаимосвязь с возникновением акушерских осложнений в разных этнических группах.

\section{Материалы и методы исследования:}

Для реализации поставленной цели были обследованы 96 женщин (средний возраст $29,4 \pm 4,6$ лет). В 1-ю группу вошли - женщины бурятской национальности, проживающие с сельской местности $(\mathrm{n}=20)$, во 2-ю группу - женщины бурятской национальности, проживающие в городе $(\mathrm{n}=26)$, и в группу сравнения вошли женщины русской этнической группы, также прошедшие обследование на полиморфизм генов тромбофилии $(\mathrm{n}=50)$.

Во всех группах методом аллель специфичной полимеразной цепной реакции (асПЦР) с последующей детекцией методом электрофореза в 3\%агаровом геле проводили определение полиморфизмы генов тромбофилии: F2 20210 A/G, F5 $1691 \mathrm{~A} / \mathrm{G}, \quad \mathrm{F} 7 \mathrm{G} / \mathrm{G}, \quad \mathrm{FGBG} / \mathrm{G}, \quad$ ITGA2 ( 2 2-интегрин)C/C, ITGB (ß3интегрин)C/C,PAI-1 (SERPINC-1) 5G/4G, MTHFR677C $>$ T, MTHFR1298A $>\mathrm{G}$, MTR2756 A $>$ G, MTRR 66A $>$ G.

Работа выполнена на базе акушерско-гинекологической клиники медицинского центра «Диамед», г. Улан-Удэ. Выполнение настоящего исследования проводилось на основании положительного решения госпитального этического комитета и после получения письменного информированного согласия обследуемых пациентов.

\section{Результаты исследование и их обсуждение:}

Средний возраст составил в 1-й группе $30 \pm 4,1$ лет, во 2-й группе $30,35 \pm 1,25$ лет, в 3 -й группе $30,45 \pm 2,35$ лет. Образование высшее в 1-й группе $30 \%$, во 2-й группе 93,4\%, в 3-й группе 92\%.

Паритет обследованных женщин представлен в таблице 1. 
Т. К. Губарь, Л. Л. Алексеева, В. Г. Стуров. Роль полиморфизма генов тромбофилии в развитии осложнений беременности родов у женщин Республики Бурятия

Паритет обследованных пациенток (n=96)

Таблицุа 1

\begin{tabular}{|c|c|c|c|c|c|c|}
\hline \multirow{2}{*}{$\begin{array}{c}\text { Число беремен- } \\
\text { ностей } \\
\text { у женщин }\end{array}$} & \multicolumn{2}{|c|}{1 группа (n=20) } & \multicolumn{2}{|c|}{2 группа (n=26) } & \multicolumn{2}{|c|}{3 группа (n=50) } \\
\hline & $\begin{array}{c}\text { Абс. } \\
\text { знач., } \mathrm{N}\end{array}$ & $\begin{array}{c}\text { Отн. } \\
\text { показ., } \\
\%\end{array}$ & $\begin{array}{c}\text { Абс. } \\
\text { знач., } \mathrm{N}\end{array}$ & $\begin{array}{c}\text { Отн. } \\
\text { показ., } \\
\% \\
\end{array}$ & Абс. знач.,N & $\begin{array}{c}\text { Отн. } \\
\text { показ., } \\
\% \\
\end{array}$ \\
\hline 1 & 5 & $25 \%$ & 9 & $34,6 \%$ & 19 & $38 \%$ \\
\hline 2 & 1 & $5 \%$ & 4 & $15,4 \%$ & 10 & $20 \%$ \\
\hline 3 & 3 & $15 \%$ & 3 & $11,5 \%$ & 12 & $24 \%$ \\
\hline 4 & 4 & $20 \%$ & 5 & $19,2 \%$ & 5 & $10 \%$ \\
\hline 5 & 2 & $10 \%$ & 3 & $11,5 \%$ & 3 & $6 \%$ \\
\hline 6 & 1 & $5 \%$ & 2 & $7,7 \%$ & 1 & $2 \%$ \\
\hline 7 и более & 4 & $20 \%$ & - & & - & - \\
\hline Bcezo & 76 & $100 \%$ & 73 & $100 \%$ & 116 & $100 \%$ \\
\hline
\end{tabular}

При обследовании установлено, что всего у пациенток 1-й группы было 76 беременностей (на 1 женщину - 3,8 беременности), во 2-й группе 73 беременности (на 1 женщину - 2,8 беременности), в 3-й группе - 116 беременностей (на 1 женщину 2,32 беременности)

В 3-й группе больше процент первобеременных $38 \%$ - по сравнению с 1-й группой $25 \%$ и 2 -й группой $-34,6 \%$.

В таблице 2 представлены исходы предыдущих беременностей у обследованных женщин.

Таблица 2

Исходы предыдущих беременностей (акушерский анамнез) пациенток n=96)

\begin{tabular}{|c|c|c|c|c|c|c|}
\hline \multirow{2}{*}{$\begin{array}{l}\text { Исходы беременно- } \\
\text { стей }\end{array}$} & \multicolumn{2}{|c|}{1 группа (n=20) } & \multicolumn{2}{|c|}{2 группа (n=26) } & \multicolumn{2}{|c|}{3 группа $(\mathrm{n}=50)$} \\
\hline & $\begin{array}{l}\text { Абс. знач., } \\
\mathrm{N}\end{array}$ & $\begin{array}{l}\text { Отн. } \\
\text { показ., } \\
\% \\
\end{array}$ & $\begin{array}{l}\text { Абс. } \\
\text { знач, } \mathrm{N}\end{array}$ & $\begin{array}{l}\text { Отн. } \\
\text { показ., } \\
\% \\
\end{array}$ & Абс. знач.,N & $\begin{array}{l}\text { Отн. } \\
\text { показ., } \\
\% \\
\end{array}$ \\
\hline $\begin{array}{l}\text { Всего беремен- } \\
\text { ностей }\end{array}$ & 76 & $100 \%$ & 73 & $100 \%$ & 116 & $100 \%$ \\
\hline $\begin{array}{l}\text { Роды в анамне- } \\
\text { зе: преждевре- } \\
\text { менные } \\
\text { своевременные }\end{array}$ & 24 & $\begin{array}{l}3,9 \% \\
31,6 \%\end{array}$ & 20 & $\begin{array}{l}5,5 \% \\
27,4 \%\end{array}$ & 25 & $\begin{array}{l}5,2 \% \\
23,2 \%\end{array}$ \\
\hline $\begin{array}{l}\text { Артифициаль- } \\
\text { ные аборты }\end{array}$ & 26 & $34,2 \%$ & 22 & $30,1 \%$ & 19 & $16,4 \%$ \\
\hline $\begin{array}{l}\text { Один самопро- } \\
\text { извольный } \\
\text { аборт в анамне- } \\
\text { зе }\end{array}$ & 6 & $7,9 \%$ & 7 & $9,6 \%$ & 20 & $17,2 \%$ \\
\hline
\end{tabular}




\begin{tabular}{|c|c|c|c|c|c|c|}
\hline $\begin{array}{l}\text { Два и более } \\
\text { самопроиз- } \\
\text { вольных аборта } \\
\text { в анамнезе }\end{array}$ & 4 & $5,2 \%$ & 4 & $5,5 \%$ & 12 & $10,3 \%$ \\
\hline $\begin{array}{lr}\text { Одна неразви- } \\
\text { вающаяся } \\
\text { беме- } \\
\text { анность } \\
\text { анамнезе }\end{array}$ & 5 & $6,6 \%$ & 5 & $6,8 \%$ & 6 & $5,2 \%$ \\
\hline $\begin{array}{lr}\text { Две и более } \\
\text { неразвиваю- } \\
\text { щихся бере- } \\
\text { менности } \\
\text { анамнезе }\end{array}$ & 3 & $3,9 \%$ & 2 & $2,7 \%$ & 7 & $6 \%$ \\
\hline $\begin{array}{ll}\text { Первая } \\
\text { менность }\end{array}$ & 5 & $6,5 \%$ & 9 & $12,3 \%$ & 19 & $16,4 \%$ \\
\hline
\end{tabular}

При анализе паритета обследованных женщин установлено, что всего у пациенток 1 группы было 76 беременностей, у пациенток 2-й группы - 73 беременности, в 3-й группе 116.

Паритет: В 1-й группе - 1,2 беременности с благоприятным исходом на 1 женщину, многорожавшие составили $30 \%$, неудачные попытки вынашивания беременности составили 0,9 на 1 женщину. Во 2-й группе выношено беременностей удачно 0,77 , в этой группе первобеременные составили $50 \%$, неудачные попытки вынашивания беременности 0,69 на 1 пациентку. В 3-й группе 0,5 беременности с благоприятным исходом, первобеременные составили $38 \%$, репродуктивные потери на 1 женщину в среднем - 0,9.

Структура экстрагенитальной патологии представлена на рисунке 1.

Рисунок 1

Структура экстрагенитальной патологии

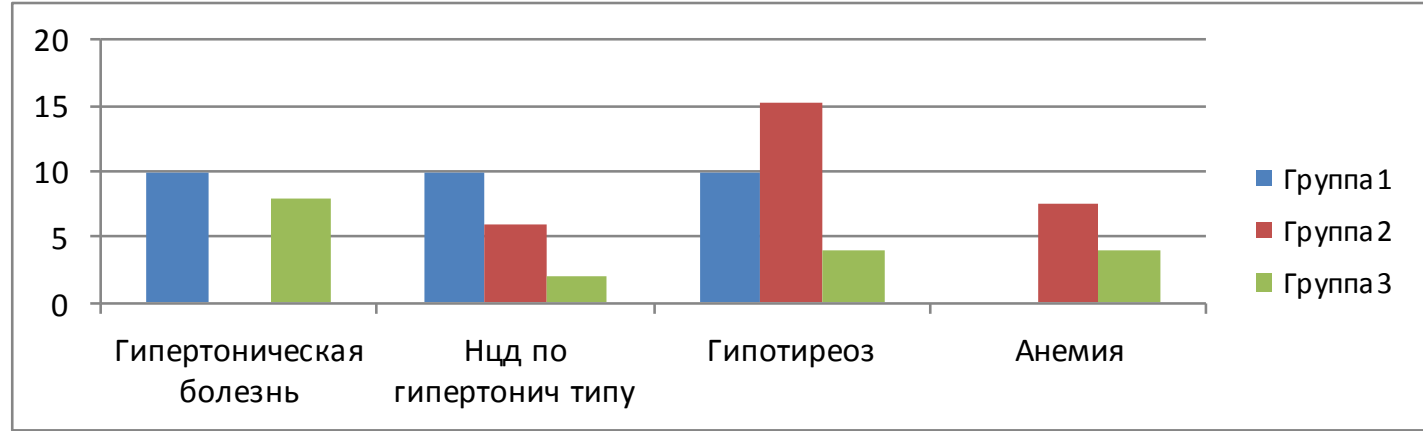

\section{$\mathbf{p} \geq \mathbf{0 , 0 0 5}$}

Гинекологическая патология представлена в 1 - й группе в $25 \%$ - миома матки, НМЦ в анамнезе у $10 \%$; во 2-й группе миома матки у $30,7 \%$; НМЦ у $23 \%$, хронический эндометрит у 7,6\%; в 3-й группе миома матки у $20 \%$, НМЦ у $2 \%$, НГЭ у $4 \%$. 
Т. К. Губарь, Л. Л. Алексеева, В. Г. Стуров. Роль полиморфизма генов тромбофилии в развитии осложнений беременности родов у женщин Республики Бурятия

Осложнения гравидарного периода у контингента обследованных пациенток проиллюстрировано на рисунке 2.

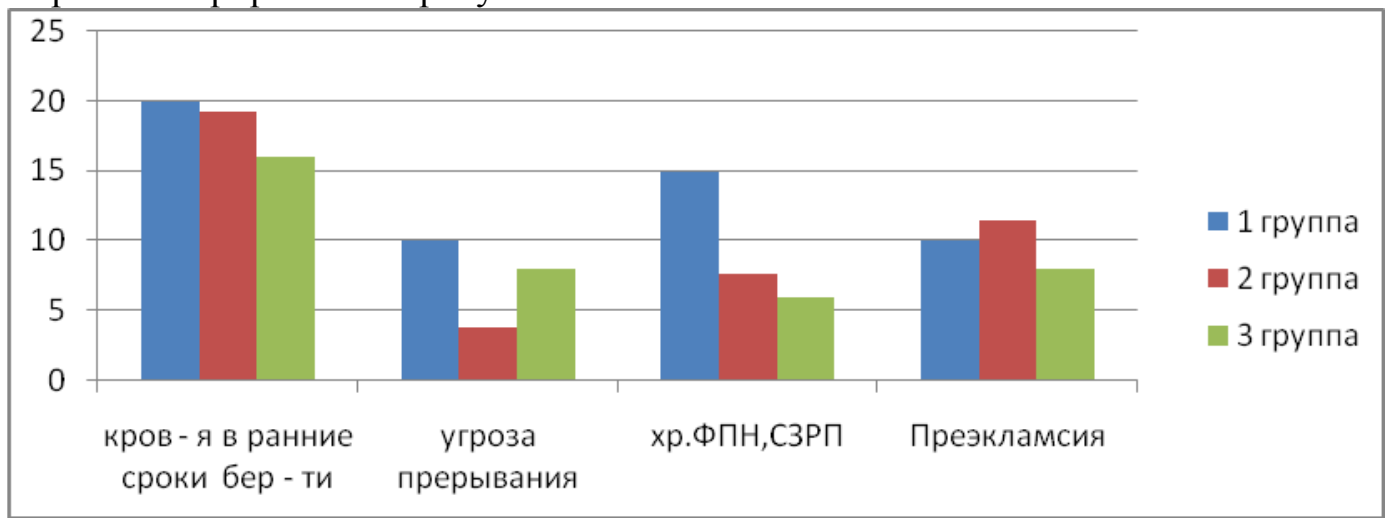

Рис. 2. Осложнения беременности. ( $\mathbf{p} \geq \mathbf{0 , 0 0 5})$

\section{Анализ исходов родов}

Осложнения со стороны матери и плода были следующими:

В 1-й группе преждевременная отслойка нормально расположенной плаценты 5\%, преэкламсия - 5\%, СЗРП - 10\%, ФПН 20\%. Средний гестационный

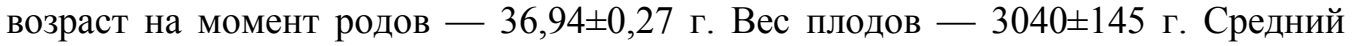
объем кровопотери - $223 \pm 65.9$ мл.

Во 2-й группе преждевременная отслойка нормально расположенной плаценты - 7,6\%, СЗРП - 7,6\%, преэкламсия 3,8\%, вызванная беременностью ги-

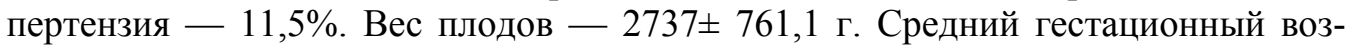

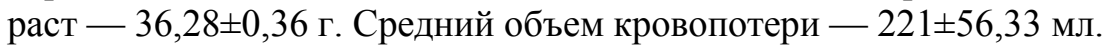

В 3-й группе преждевременная отслойка нормально расположенной плаценты - 2\%, ФПН - 14\%, СЗРП - 8\%, преэкламсия 4\%, вызванные беременностью гипертензия $10 \%$, антенатальная гибель плода $-2 \%$. Средний гестационный возраст - 34,38 $\pm 0,57$ г. Средний объем кровопотери $3,133 \pm 295$ г.

Результаты тестирования на наличие полиморфизма в генах F2, F5, F7, FGB, ITGA2 - $\alpha 2$ интегрин, ITGB $-\beta 3$ интегрин не выявлено достоверных отличий $(\mathrm{p}>0,5)$.

В качестве неблагоприятных рассматривались аллельные полиморфизмы генов системы гемостаза и данные по носительству указанных генотипов представлено в табице 3.

Таблица 3

Полиморфизмы генов системы гемостаза

\begin{tabular}{|c|c|c|c|c|}
\hline Группы исследования & \multicolumn{4}{|c|}{ Генотип } \\
\hline \multicolumn{5}{|l|}{$P A I-15 G / 4 G$} \\
\hline & $5 \mathrm{GG}$ & $5 \mathrm{G} 4 \mathrm{G}$ & $4 \mathrm{G} 4 \mathrm{G}$ & $5 \mathrm{G} 4 \mathrm{G}+4 \mathrm{G} 4 \mathrm{G}$ \\
\hline Группа $1(n=20)$ & -- & $18(90 \%)$ & $2(10 \%)$ & $20(100 \%)$ \\
\hline Группа 2(п=23) & $6(23 \%)$ & $16(61,5 \%)$ & $4(15,3 \%)$ & $20(76,8)$ \\
\hline Группа $3(\Pi=50)$ & $10(20 \%)$ & $12(24 \%)$ & $28(56 \%)$ & $40(80 \%)$ \\
\hline \multicolumn{5}{|l|}{ MTHFR $677 C>T$} \\
\hline & $\mathrm{CC}$ & $\mathrm{CT}$ & TT & $\mathrm{CT}+\mathrm{TT}$ \\
\hline
\end{tabular}




\begin{tabular}{|c|c|c|c|c|}
\hline Группа 1(п=20) & $8(40 \%)$ & $10(50 \%)$ & $2(10 \%)$ & $12(60 \%)$ \\
\hline Группа 2(п=26) & $16(61,6 \%)$ & $10(38,4 \%)$ & 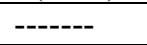 & $10(38,4 \%)$ \\
\hline Группа 3(п=50) & $14(28 \%)$ & $20(40 \%)$ & $16(32 \%)$ & $36(72 \%)$ \\
\hline \multicolumn{5}{|c|}{ MTHFR 1298A $>G$} \\
\hline & AA & AG & GG & $\mathrm{AG}+\mathrm{GG}$ \\
\hline Группа 1(п=20) & $8(40 \%)$ & $10(50 \%)$ & $2(10 \%)$ & $12(60 \%)$ \\
\hline Группа 2(п=26) & $14(53,8 \%)$ & $8(30,7 \%)$ & $4(15,3 \%)$ & $12(46 \%)$ \\
\hline Группа $3(\Pi=50)$ & $16(28 \%)$ & $20(40 \%)$ & $14(32 \%)$ & $34(72 \%)$ \\
\hline \multicolumn{5}{|l|}{$M T R 2756 A>G$} \\
\hline & AA & $\mathrm{AG}$ & GG & $\mathrm{AG}+\mathrm{GG}$ \\
\hline Группа 1(ח=20) & $12(60 \%)$ & $6(30 \%)$ & $2(10 \%)$ & $8(40 \%)$ \\
\hline Группа2(п=26) & $14(53,8 \%)$ & $8(30,7 \%)$ & $4(15,3 \%)$ & $12(46 \%)$ \\
\hline Группа3(п=50) & $30(60 \%)$ & $16(32 \%)$ & $4(8 \%)$ & $20(40 \%)$ \\
\hline \multicolumn{5}{|l|}{ MTRR 66A>G } \\
\hline & AA & $\mathrm{AG}$ & GG & $\mathrm{AG}+\mathrm{GG}$ \\
\hline Группа1(п=20) & $4(20 \%)$ & $16(80 \%)$ & -- & $16(80 \%)$ \\
\hline Группа $2(п=26)$ & $16(61,5 \%)$ & $8(30,7 \%)$ & $2(7,7 \%)$ & $10(38,4 \%)$ \\
\hline Группа $3(\Pi=50)$ & $14(28 \%)$ & $26(52 \%)$ & $12(24 \%)$ & $38(76 \%)$ \\
\hline
\end{tabular}

Условные сокращения: PAI (SERPIN - 1) антагонист тканевого активатора плазминогена, MTHFR - метилентетрагидрофосфатредуктаза, MTR - метионин-редуктаза, MTRR - метионинсинтаз-редуктаза.

Процент патологической позитивности по полиморфизмам генов фолатного цикла составил: 1 группе - 30\% патологические гомозиготы, 2 группе -38\% патологические гомозиготы, 3 группе - 96\% патологические гомозиготы.

По гену MTHFR(C677T), регулирующий метаболизм фолиевой кислоты в 1 группе - 10\%, 2-й группе - отсутствуют, 3 группе - 32\%.

Ген MTRR(66A $>$ C), регулирующий метаболизм витамина B12: 1 - группа $-10 \%, 2$-я группа $-7,6 \%$, в 3-й группе $-24 \%$

Патологические гомозиготы по гену SERPINC-1 (PAI-1 5G/4G): в 1-й группе $-10 \%$, во 2-й группе $-15 \%, 3$-й группе $-56 \%$.

Динамика изменения плазменной концентрации гомоцистеина представлена на рисунке 3.

Средний уровень концентрации гомоцистеина в 1 - группе составляет $(6,8 \pm 1,4$ мкМоль/л), во 2 - группе - $(4,7 \pm 1,6$ мкМоль/л) в 3 - группе $(4,68$ $\pm 1,65$ мкМоль/л). В 1-й группе показатель гомоцистеина выше, возможно это связано с особенностями питания, так как сюда входят женщины бурятской этнической группы, проживающие в сельской местности. 
Т. К. Губарь, Л. Л. Алексеева, В. Г. Стуров. Роль полиморфизма генов тромбофилии в развитии осложнений беременности родов у женщин Республики Бурятия

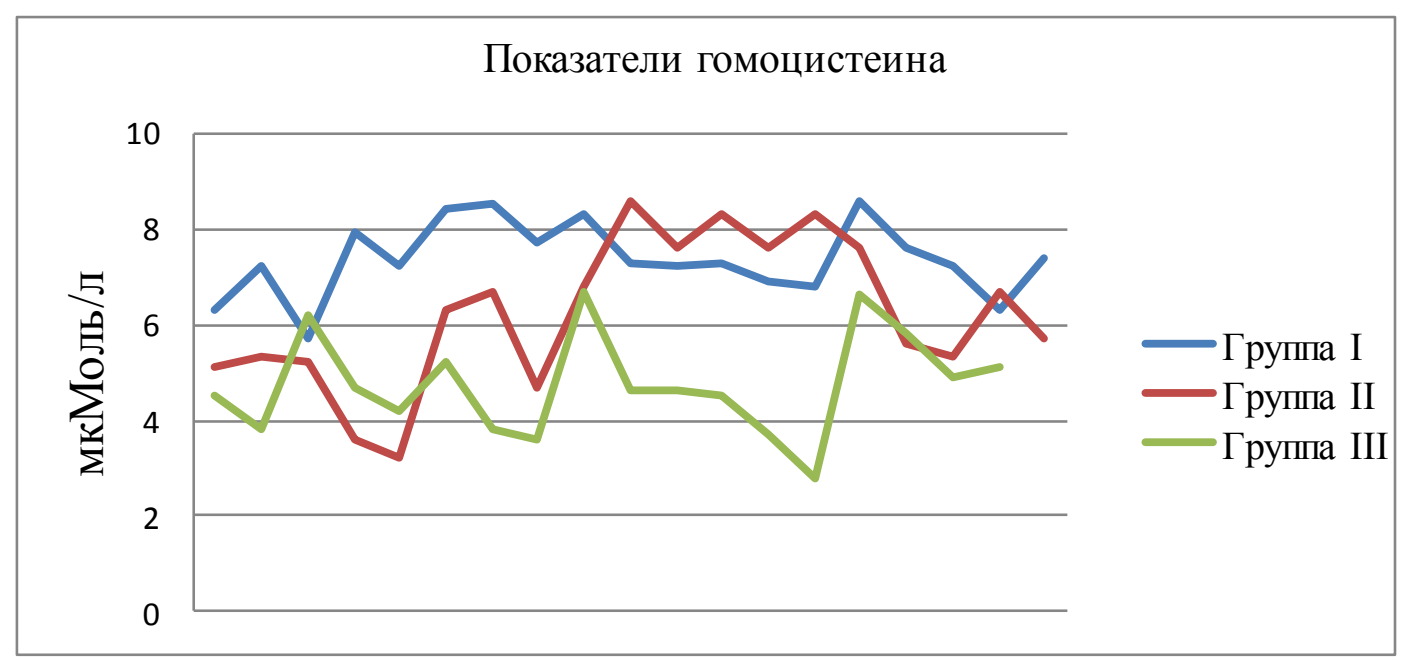

Рис. 3. Показатели гомоцистеина

Bblвodbl. В соизмеримых по возрасту и социальному статусу группах обследуемых, частота развития осложнений беременности не имеет значимых различий, хотя частота встречаемости патологических генотипов больше в группе европейской популяции, что согласуется с данными зарубежной литературы о высоком проценте бессимптомного носительства гетерозиготных полиморфизмов в гене PAI-1 (5G/4G) среди европейской популяции (до 41,7\%) [9].

\section{Литература}

1. Акушерство. Национальное руководство / Э. К. Айламазян [и др.]; под ред. В. Е. Радзинского. М.: ГОЭТАР. Медиа. 2007. 1064 с.

2. Макацария А. Д., Бицадзе В. О., С. В. Акиньшина. Тромбозы и тромбоэмболии в акушерско-гинекологической клинике. Молекулярно-генетические механизмы и стратегия профилактики тромбоэмболических осложнений, руководство для врачей. М.: Мед. информ. агентство, 2007. 1200 с.

3. Макацария А. Д., Бицадзе В. О. Тромботическая и противотромботическая терапия в акушерской практике. М.: Триада Х, 2003. С. 904.

4. Макацария А. Д. Бицадзе В. О. Метаболический синдром и тромбофилия в акушерстве и гинекологии. М.: Мед. информ. агентство. С 214-216.

5. Макацария А. Д., Бицадзе В. О. Профилактика повторных осложнений беременности в условиях тромбофилии. М.: Триада X, 2008.

6. Газиева И. А., Чистякова Г. Н., Ковалев В. В. Полиморфизмы генов фолатного обмена и показатели функционального состояния эндотелия в ранние сроки беременности: факторы риска развития гестационных осложнений //Акушерство и гинекология. 2013. № 1. С. 57-61.

7. Долгушина В. Ф., Вереина Н. К. Генетические и приобретенные факторы риска тромбозов у женщин с акушерской патологией в анамнезе // Акушерство и гинекология. 2011. № 3. С. 27-31.

8. Лоскутова Т. А. Анализ форм тромбофилии у беременных с акушерскими и перинатальными осложнениями при проэкламсии // Акушерство и гинекология. 2013. № 10. С. 23-27. 
9. Jeng J. R. Association of PAI-1 gene promoter 4G/5G polymorphism with plasma PAI1 activity in Chinese patients with and without hypertension // Am J Hypertens. 2003. Vol. 16, N. 4. P. 290-296.

\section{ROLE OF POLYMORPHISMS OF THROMBOPHILIA GENES IN COMPLICATION DEVELOPMENT OF PREGNANCY AND CHILDBIRTH IN WOMEN IN THE REPUBLIC OF BURYATIA}

\section{Tatiana K. Gubar}

Obstetrician-Gynecologist, Post-graduate Student, Department of Obstetrics and Gynecology with the course of Pediatrics, Dorzhi Banzarov Buryat State University

24a Smolina St., Ulan-Ude 670000, Russia

Lilia L. Alekseeva

Doctor of Medical Sciences, Associate Professor,

Acting Chief Physician,

Republican Perinatal Center of the Ministry of Health of the Republic of Buryatia Department of Obstetrics and Gynecology with Course of Pediatrics, Dorzhi Banzarov Buryat State University

54, Lenin st., Ulan-Ude, 670031 Russia

E-mail: 1.alekseeva09@mail.ru

Victor G. Sturov

Doctor of Medical Sciences, Professor of Postgraduate Medical Education Centre of the Institute of Retraining and Advanced Training, Novosibirsk National Research State University, Novosibirsk, Russia

2, Pirogov St., Novosibirsk, 630090 Russia

E-mail: sturov@mail.ru

The analysis of the survey results of 96 women in the Republic of Buryatia (including 20 women of the Buryat nationality, living in a remote area, 26 women of the Buryat nationality, residing in the city, 50 women of Russian ethnic group) showed no reliably significant differences in the development of pregnancy complications and birth outcomes, although the frequency of occurrence of abnormal genotypes predisposing to the development of more thrombophilia in a European population.

Key words: thrombophilia, genetic defects, complications of pregnancy, parity homocysteine 